Revue de l'Institut des langues et cultures

d'Europe, Amérique, Afrique, Asie et Australie

$31 \mid 2018$

Récits fictionnels et non fictionnels liés à des

communautés professionnelles et à des groupes spécialisés

\title{
Using Science Fiction as a Teaching Tool in ESP Classes for Science Students
}

L'utilisation de la science-fiction comme outil pédagogique dans le cadre de

l'anglais de spécialité scientifique

\section{Marie Thévenon}

\section{OpenEdition}

\section{Journals}

Electronic version

URL: http://journals.openedition.org/ilcea/4688

DOI: $10.4000 /$ ilcea.4688

ISSN: 2101-0609

\section{Publisher}

UGA Éditions/Université Grenoble Alpes

\section{Printed version}

ISBN: 978-2-37747-043-3

ISSN: 1639-6073

Electronic reference

Marie Thévenon, "Using Science Fiction as a Teaching Tool in ESP Classes for Science Students », ILCEA [Online], 31 | 2018, Online since 06 March 2018, connection on 01 May 2019. URL : http:// journals.openedition.org/ilcea/4688; DOI : 10.4000/ilcea.4688

This text was automatically generated on 1 May 2019.

(C) ILCEA 


\section{Using Science Fiction as a Teaching Tool in ESP Classes for Science Students}

L'utilisation de la science-fiction comme outil pédagogique dans le cadre de l'anglais de spécialité scientifique

\section{Marie Thévenon}

1 As Irène Langlet (2006) explains, in the academic world, reading science fiction is still a relatively rare activity due to a heritage of prejudice and stereotypical images regarding the genre. Although works such as Aldous Huxley's Brave New World (1931), George Orwell's Nineteen Eighty-Four (1949), or Margaret Atwood's The Handmaid's Tale (1981) have now become part of the canon of the genre, their science fiction nature has regularly been masked by labels such as "speculative fiction", often relegating the term "science fiction" to mere pulp fiction, a genre generally looked down upon. ${ }^{1}$ These observations may be true for the study of science fiction in literature classes, but what about its possible use in the ESP classroom?

her article on "How scientific is science fiction? From 'Scientifiction' to Cyberpunk and beyond" (2004), Andreolle discusses the link between science fiction and FASP studies ${ }^{2}$ and pleads in favour of a "vaster definition (or perhaps sub-category definition) closer to the widely-embracing Anglosaxon expression expert fiction, with a label such as FASS ( fiction à substrat spécialisé) which would allow for the inclusion of popular genres like science fiction" (2004: 153). It is within this "vaster definition" or "sub-category definition" that we place this study related to the possible use of science fiction in an ESP context of students specialising in astrophysics and biotechnology.

We start with a brief historical overview of the popular genre of science fiction, by exploring its beginnings and the important role it plays in the field of science popularisation. We then go on to present the pedagogical potential of the genre and a few specific examples of the way in which these works can be used in the classroom and to further the popularisation of science. 


\section{General overview of science fiction as a genre}

\subsection{Pinpointing a beginning}

4 It is first of all important to differentiate between science fiction and the fantasy genre, and though both of them tend to "share the same shelves in Anglosaxon bookstores", as Andreolle explains, "the vital difference is that science fiction deals with the rational, empirical environment [...] whereas fantasy literature deals with the irrational (dragons, magic and other supernatural phenomena as in Lord of the Rings)" (2004: 153). Science fiction stems from the mixture of science and fiction, unlike fantasy.

However, pinpointing its beginnings is a difficult task since different interpretations of the term lead to different beginnings or precursors. According to Ruaud and Colson (2014), Thomas Moore's Utopia (1516) marks the birth of the origins of science fiction, and Mary Shelley's Frankenstein (1818) ${ }^{3}$ could be placed somewhere within the "proto-History" of science fiction. Even though the term was not invented at the time, many works already contained the essence of what would later become "science fiction". According to Ruaud and Colson (2014), during the $18^{\text {th }}$ century, scientists and novelists illustrated the aspirations of modernity with "fantastic voyages" ("voyages fantastiques"), and in the $19^{\text {th }}$ century, the French defended the idea of a "merveilleux-scientifique", whereas the English focused on what they called "scientific romance". The $19^{\text {th }}$ century was also marked by the close link between technology and science, an illustration of which is Jules Verne's Nautilus which combines submarine technology and the pure science of its electrical propulsion. ${ }^{4}$

6 In the $20^{\text {th }}$ century, the Americans gave a name to this literary tradition, with Hugo Gernsback's "scientifiction", a term which, for legal copyright reasons and in what could be called "a twist of fate", became "science fiction" when he created his new magazine, Amazing Stories (1926). The history of American science fiction is closely linked to the evolution of editorial markets, from slicks to pulps (Colson \& Ruaud, 2014: 158). Science fiction became the domain of pulps, especially after the creation of All-Story magazine in 1905, which placed American science fiction "resolutely in the domain of popular or 'low-brow' culture" (Andréolle, 2004: 154), as opposed to European fiction which "evolved from more respectable literary forms (the Gothic romance or the Utopian narrative, for instance)" (ibid.).

7 Science and science fiction are thus closely intertwined both historically and technologically. Science fiction tends to speculate about the future and in so doing helps to educate the non-specialist about tomorrow's new technology. It is, in fact, for this very reason that editors such as Gernsback took an active part in the popularisation of the genre.

\subsection{Science fiction and science popularisation}

Science fiction starts off, according to Gernsback, as a way of making specialised scientific knowledge more comprehensible for the general public by popularising scientific innovations. A certain number of sci-fi writers started out as science journalists and then turned to writing fiction in order to place the technological innovations they spoke of in the context of a future era and be able to picture the possible outcomes of such changes 
in society (hence the popular narratives of utopias and dystopias). Although different branches of science fiction tend to focus more on scientific accuracy and others on pure entertainment (such as space operas like Star Wars, for example, which does not pay much heed to scientific accuracy), we will be focusing more on the ones which "respect the science", as much as possible.

In his book on science fiction, Baudin (1971) explains the importance of science popularisation in a world which is otherwise difficult to penetrate for non-experts, explaining how talented scientific writers manage to render scientific advances accessible for the general public through the links between scientific research, popular science and science fiction. The construction of new knowledge in scientific laboratories leads to popular science and mediation, an in-between space in which experts and the general public can debate about science and society.

Somewhere, a little beyond all this, is an external sphere in which art and science intermingle and art finds a source of inspiration, whether through prospective utopian scenarios, through FASP or through science fiction, as shown by Fries:

Fig. 1. - Different spheres of scientific discourse

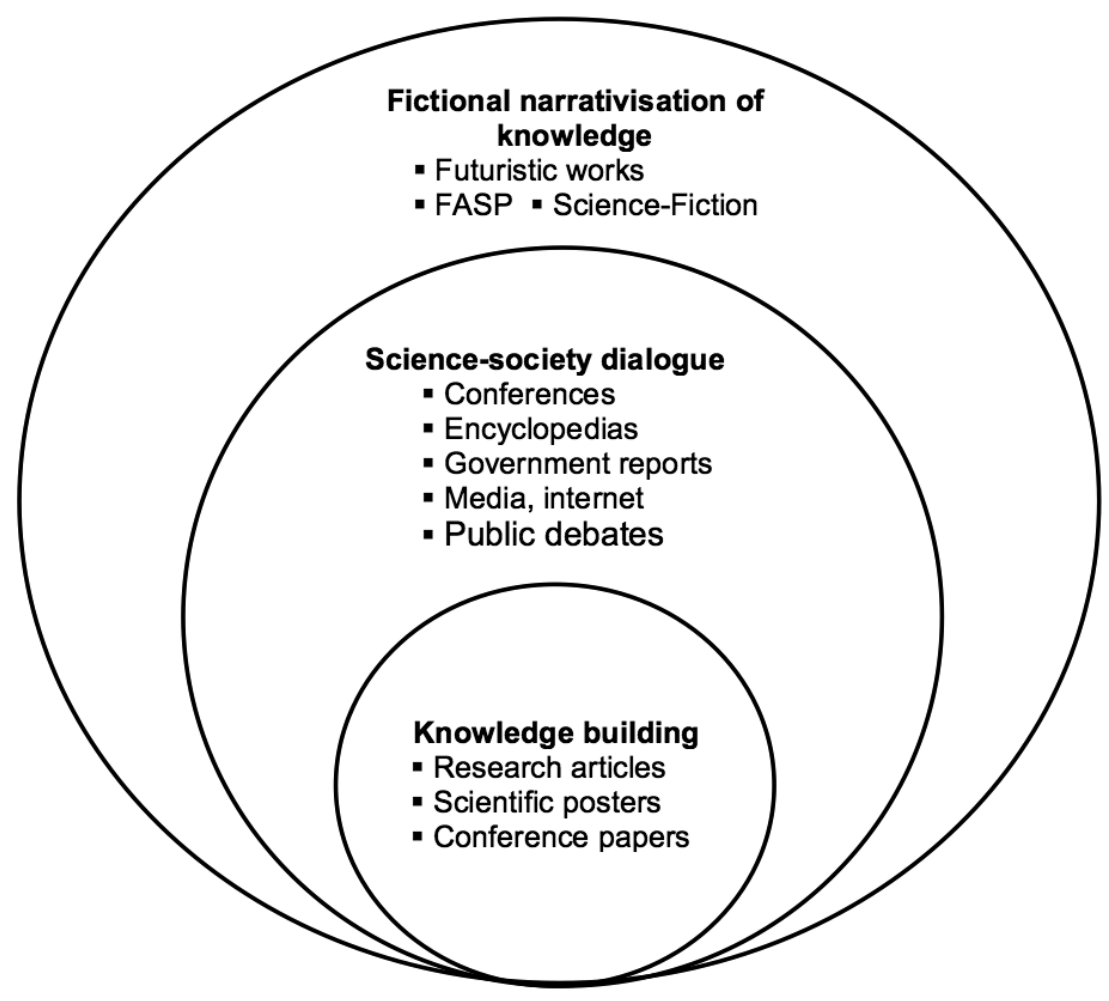

ADAPTED FROM FRIES (2016: 33)

(EDITOR'S TRANSLATION)

11 As an example of this type of intermingling, astrophysics presents a good case in point. Over the recent years, astrophysics has seen a sudden surge in popularity. One example of this is the highly acclaimed comedy TV sitcom, The Big Bang Theory, whose main characters are physicists at CalTech. Another example is the general public's interest for the activities taking place at CERN in Geneva as we learn more and more about supermassive black holes, Higgs Boson particles and gravitational waves. ${ }^{6}$ Many astrophysicists have indeed risen to relative fame by focusing on public understanding of 
science programmes. Although Albert Einstein was by no means a science populariser, his image, coupled with what is probably the most famous equation so far, $\mathrm{E}=\mathrm{mc}^{2}$, has come to represent an image of the archetype of the "scientist" in the $20^{\text {th }}$ century, as Edison and Tesla before him, and is now undoubtedly one of the icons of scientific pop culture.

Today, the Royal Astronomical Society, as well as quite a few notable prominent professors such as Stephen Hawking, Carl Sagan, Neil deGrasse Tyson or Lawrence Krauss, to name but a few, are active in the popularisation of astrophysics which fascinates the general public. Most of these professors have written books focusing on popular science such as, for example, A Brief History of Time: From the Big Bang to Black Holes (1988) by Stephen Hawking and Death By Black Hole and Other Cosmic Quanderies (2007), Space Chronicles: Facing the Ultimate Frontier (2014) by Neil deGrasse Tyson. These scientists have also taken part in television programmes, such as Cosmos, A Personal Voyage (Sagan, followed by deGrasse), for example, and they all take part in public conferences and debates in front of live public audiences. We also note their high visibility in popular culture through cameo appearances: Stephen Hawking makes regular appearances in The Big Bang Theory, for example, confirming his status as a major pop culture figure.

In the same vein, YouTube channels like 60 symbols, created by the University of Nottingham ${ }^{7}$, and PBS Space Time ${ }^{8}$, specialise in familiarising viewers with concepts from physics, astronomy and mathematics and explain complicated theories using metaphors or concrete experiments and experiences from everyday life. These channels have hundreds of thousands of subscribers and millions of views. It is thus becoming "part of the job" to write or talk about one's "science" to the public, as is also illustrated by contests for doctoral students such as Dance your Ph.D (transforming a PhD research subject into dance, choreography and costumes) or Three-minute thesis in which doctoral students must explain their thesis "in simple words" and three minutes.

These popularisation programmes are not only limited to "pure science" since many also decide to start from fiction and explain the "science" in it, even when, at first glance, the fiction is not necessarily "realistic science". Works such as The Science of Dr Who (2006) ${ }^{9}$ or The Science of Interstellar (2014) take specific points from the narrative and explain in what way they are scientifically possible. ${ }^{10}$ In the same way, some big "science" conferences are directly linked to science fiction and tend to blur the line between fiction and reality, or at least show in what way scientific research and science fiction are not all that far apart. This is the case, for example, of The Isaac Asimov Debate, an annual event presided by Neil deGrasse Tyson ${ }^{11}$ who also specialises in radio and television series. In his radio programme Star Talk, which later became a TV show, he brings artists and scientists together to show how art and science intertwine. The idea behind the show is to "get more artists interested in science so that they can fold the science into their art and take us to new places" (Season 1, episode 2, 27/04/15).

The general public is thus increasingly receptive to science popularisation, which makes it possible for blockbusters and bestsellers to focus on accurate science and even base their fiction on extended knowledge of astrophysics. In so doing, they too participate actively in science popularisation and education. All these elements point towards the high potential of science fiction as an ESP teaching tool for specialised students, examples of which we discuss in the following section. 


\section{Science Fiction in the ESP classroom}

\subsection{Science fiction's pedagogical potential}

As a great admirer of Jules Verne and a connoisseur of the Anglosaxon utopias, Gernsback founded the magazine Modern Electrics in 1908. In "Fifty Years Hence", a speech he gave on $5^{\text {th }}$ April 1957 before the joint meeting of the Michigan Institute of Radio Engineers and the American Radio Relay League at the Henry Ford Auditorium in Michigan, Gernsback expressed his astonishment at the American public's general ignorance of technology:

It rankled me that there could be such ignorance in regard to science and I vowed to change the situation if I could. A few years later, in 1908, I turned publisher and brought out the world's first radio magazine, Modern Electrics, to teach the young generation science, radio, and what was ahead for them. (Quoted in Ashley, 2000:

28)

Although his first magazines only contained speculative non-fictional articles, which aimed essentially at stimulating interest in scientific advance, before long he was also publishing fiction. The stories were not so much science fiction as scientific instruction in narrative form. In April 1916, Gernsback wrote a powerful editorial entitled "Imagination versus Facts", encouraging his readers to write their own stories and speculative articles. Gernsback's "science fiction" "extrapolated from existing known science to suggest future inventions and what they might achieve; and all for the sole purpose of stimulating the ordinary person with a penchant for experimenting with gadgets, into creating that future" (Ashley, 2000: 34). ${ }^{12}$ Gernsback also wrote his own fiction (cf. Ralph 124C $41+{ }^{13}$ ). In the editorial of the first issue of Amazing Stories in April 1926, Gernsback gives a definition of the term "scientifiction": "By 'scientifiction' I mean the Jules Verne, H. G. Wells and Edgar Allan Poe type of story-a charming romance intermingled with scientific fact and prophetic vision". He adds:

Not only do these amazing tales make tremendously interesting reading-they are also always instructive. They supply knowledge that we might not otherwise obtain -and they supply it in a very palatable form. For the best of these modern writers of scientifiction have the knack of imparting knowledge, and even inspiration, without once making us aware that we are being taught.

(My italics)

This quotation highlights the inherently pedagogical nature of science fiction hidden behind the entertaining format. By "educating" and "instructing" the public, science fiction thus leads to the popularisation of science.

If science popularisation is at the heart of science fiction, it also serves a very scientific purpose. Researchers in technology indeed rely, in part, on science fiction to find inspiration for new discoveries. In Rosen's article entitled "Why Today's Inventors Need to Read More Science Fiction" (2013), two MIT Media Lab researchers, Dan Novy and Sophia Brueckner, explain how studying the works of authors such as Philip K. Dick and Arthur C. Clarke helps designers "working in the very real world" not just to come up with ideas for new gadgets, but also to anticipate their consequences. As Gunn explains on his website, "The kinds of subjects that can be taught through science fiction involve all the social and physical sciences, history, ideas, futurology, religion, morality, ecology, reading skills, and many others"-in view of which, it only seems natural to assume that 
science fiction could also be used effectively in the ESP classroom with Science and Technology students.

The examples of fiction we discuss are based on scientific knowledge which is simplified in order to help the general public to understand the storyline. As such, it helps domainspecialist students to work on their English but also to learn about how to popularise their scientific knowledge. Regarding the science fiction used in the ESP classroom, we deliberately chose two different disciplines (astrophysics and biotechnology) and different formats (a film, a video game and a novel) to highlight the variety that science fiction offers in the ESP teaching context, particularly in regard to the language skills targeted, listening comprehension in the case of a film or a video game, reading comprehension in the case of a novel.

\subsection{Science fiction for an astrophysics class: science and popularisation}

\section{a) The film Interstellar}

21 The first case we present is taken from the film Interstellar whose director, Christopher Nolan, decided to work in close collaboration with Kip Thorne, a well-known American theoretical physicist and retired professor of physics at Caltech. It is thanks to him that the "science of Interstellar" (which is also the name of the book Thorne wrote on the subject) is as accurate as can be in a film..$^{14}$ As Thorne declared during a conference in Copenhagen in 2014, the aim was to make a film "that would embody general relativity and its very fabric in a way that would be understandable [and compelling] to the general public". In fact, this collaboration was not only about science helping entertainment; with the amount of funding put into the film's visual effects, it also helped astrophysicists to better visualise objects which only exist in theory and have never been seen by the human eye before. This is the case of black holes, but also of wormholes, one of which was shown for the first time as a sphere in the film. The director's intention to make the film as scientifically accurate as possible and still maintain its entertainment value, makes it an ideal subject for an ESP class. By selecting specific examples from the film, one possible exercise would be to ask ESP students specialising in astrophysics to judge how realistic the film is, what concessions/departures from realism are made to render the film as entertaining as possible for the general public, and question them regarding the popularisation strategies involved. One such example could be the description of the "wormhole" which the characters use to travel from one part of the galaxy to another. ${ }^{15}$

Kip Thorne has admitted that, although Interstellar strives to stay as true to "the science" as possible, for reasons of entertainment, there were some departures from realism as far as the depiction of travelling through the wormhole was concerned. Furthermore, in order to enable the non-specialist audience to understand the concept of a wormhole, a highly visual depiction is made during the conversation between two of the main characters, who also happen to be astrophysicists and astronauts: Romilly, an astrophysicist, takes a piece of paper, draws two crosses on either side of it, folds it and puts a pen through the two crosses, linking them together and showing how to get from point A to point B instantaneously thanks to a wormhole. ${ }^{16}$ Although the characters in Interstellar are supposed to be working for NASA and should thus already know what a wormhole is, this simplistic explanation, which is obviously only there for the film 
audience, is rendered plausible by the fact that the main character has not worked with NASA for several years since he became a farmer and has hence not kept up to date with the advance of science. A very similar scene appears in another science fiction film, Event Horizon, in which a specialist explains what a wormhole is in terms considered too complicated by his team who ask him for a simpler explanation. ${ }^{17}$ The use of such popularisation strategies could lead to a discussion on the notion of "layman's terms", by firstly explaining what the expression means (i.e.: to make something understandable by a non-specialist), leading on to some vocabulary work on what the students consider to be layman's terms, or not, in the extracts seen. In the Event Horizon extract, it is interesting to compare the first explanation with the second and the reaction produced on the audience. What the scientist initially assumes are layman's terms clearly aren't for his audience who ask him to explain it all again "in English". The teacher could ask the students to write down the terms which aren't understandable by the layman ("a beam of gravitons", "Weyl tensor dynamics", etc.) and explain why the second attempt is more successful (simpler vocabulary and a visual demonstration). The visual depiction in the film can be compared with the description Kip Thorne gives in the documentary about the film Interstellar where he uses the image of an actual wormhole in an apple, which is where the original expression came from. ${ }^{18}$ These extracts and exercises show the students how such images help the audience to understand the scientific concepts crucial to the narrative, and highlight the importance of science popularisation in the realm of entertainment.

The use of metaphors to illustrate the complexity of certain concepts has become a common theme within the realm of science popularisation. In his 2012 book, Gravity's Engines: The Other Side of Black Holes, Caleb Scharf discusses "some of the most extreme and complex astrophysical phenomena in the known universe-black holes-by deploying a whole battleship's worth of analogy, metaphor [and] simile" (2013). In his 2013 article on the subject, "In Defense of Metaphors in Scientific Writing", he explains that metaphors help people to "build an intuition for a problem, by relating it to something else", which is why they are used so frequently by scientists. Terms such as "spaghettification" are used to refer to the vertical stretching and horizontal compression of objects into what resembles spaghetti when an object comes close to a black hole and the term has now entered the realm of specialised vocabulary. ${ }^{19}$ This very visual depiction of something which is highly theoretical is what speaks most to the non-specialist, and so it is no wonder that the same type of images reappear in science fiction. Anthropomorphism is also commonly used, much to the dislike of some specialists who argue that phenomena such as black holes should not be "monsterised"-and in this respect, we note that in Interstellar, the black hole is called Gargantua, a reference to Rabelais' giant. These metaphors and visual depictions of theoretical concepts are also elements which promote linguistic analysis in an English class, during which other metaphors to describe other phenomena are also inevitably explored.

Finally, Interstellar uses its narrative to illustrate astrophysical concepts such as time relativity. Rather than stick to theoretical concepts, the film explicitly shows the effect of each character's perception of time as they approach a black hole. The audience follows the astronauts' timeline as they explore a planet on which one hour for them is equivalent to 7 years on earth, and when they return 23 years have elapsed. This theoretical concept has very concrete consequences on the storyline since the hero's 
children soon grow older than he is and its depiction in the film allows non-specialists to grasp the concept of time relativity.

\section{b) Astrophysics-themed video games}

Astrophysics has also made its way into video games. From the very first Space Invaders (1978) to today's more realistic "first-person shooters", video games have found great inspiration in science fiction's intergalactic space travels. The popularity of highly developed realistic video games underscores the fact that scientific accuracy is a selling point, as is the case of games such as Space Engineers which describes itself on the digital distribution platform Steam as:

[A] game about engineering, construction, exploration and survival in space and on planets. [...]

Space Engineers features a realistic, volumetric-based physics engine: everything in the game can be assembled, disassembled, damaged and destroyed. [...] Space Engineers is inspired by reality and by how things work. Think about modern-day NASA technology extrapolated 60 years into the future. Space Engineers strives to follow the laws of physics and doesn't use technologies that wouldn't be feasible in the near future.

This description comes close to what Gernsback strived for in his magazines. Similarly, the title of the game Half-Life (1998) refers to a term commonly used in nuclear physics. ${ }^{20}$ The game centres on a theoretical physicist and focuses on a physics experiment which goes horribly wrong (using a fictitious phenomenon, called the "resonance cascade"). The first minutes of the game immerse the player in the laboratory and experimental environment in which the main character (impersonated by the player) works. The vocabulary used is professional and offers an immersion experience which could be usefully put to use in an ESP classroom.

The first five minutes of the game ${ }^{21}$ allow the player to see his character's point of view as he enters Black Mesa, the complex in which he works. A woman's voice can be heard over a loud speaker reminding the personnel of the different security requirements they need to submit to in order to carry on working within the facility:

A reminder to all Black Mesa personnel: regular radiation and biohazard screenings are a requirement of continued employment in the Black Mesa research facility. Missing a scheduled urine analysis or radiation check-up is grounds for immediate termination. If you feel you have been exposed to radioactive or other hazardous materials in the course of your duties, contact your radiation safety officer immediately. Work safe, work smart. Your future depends on it.

In this precise context, student activity can focus on the different security requirements within the facility and analysis of how realistic they are compared to their own experience. They can also be made aware of expressions specific to such cultural environments, as, for example, the way in which the time is announced ("nineteen hundred hours", rather than "seven p.m.").

As Dr Freeman, the main character, arrives at his lab, the player finds himself in the midst of a conversation with his colleagues around the subject of the experiment which is about to take place. ${ }^{22}$ These exchanges can be used as an oral comprehension activity in which students can be asked to identify the specialised terminology-“We've just sent the sample down to the test chamber", "We've boosted the anti-mass spectrometer to $105 \%$, bit of a gamble but we need the extra resolution", "I'm afraid we'll be deviating a bit from standard analysis procedures today, Gordon", "if you follow standard insertion 
procedures, everything will be fine"-and decide to what degree such exchanges are within the non-specialist player's grasp.

Such activities can be used effectively in an ESP astrophysics class in the double objective of not only working on the professional and specialised terminology but also raising awareness of how the science is popularised and made accessible to the non-specialist player. At a more creative level, students could also be asked to enact a role play based on the classic specialist/non-specialist tandem (Isani, 2009) strategy and thus experience for themselves the complexities of having to explain a highly scientific phenomenon or process to a layperson.

\subsection{Science fiction for a biotechnology class: science and ethics}

However paradoxical it may appear, in science fiction, it is not only the "science" that is useful for ESP, but also the fiction. Indeed, the full ethical and societal consequences of our present technological choices can only be depicted from the point of view of the future, through fictional narratives. From robotics and artificial intelligence (cf. Isaac Asimov, for example) to the internet and the brain-computer interface (explored in Neil Gibson's Neuromancer (1984), for instance) and, of course, biotechnology and ethical issues are often at the heart of the stories told.

Margaret Atwood's Oryx and Crake (2003) is considered by the author herself as a speculative novel, which deals with science already within our possibilities, hence the precautionary side to the narrative. It is a dystopia which starts off in a post-Apocalyptic dimension in which there is but a lone human survivor in a world otherwise populated only by genetically-engineered artificial beings created by man. The "new humans" are the result of a "mad scientist" archetype character's "evil plan" to eradicate human beings and replace them by a new race of innocently childlike herbivores. The narrative is divided into the lone survivor's tale of survival in this new world and analepses or flashbacks to his past life in a world where bioengineers "play God" without being held back by ethical considerations. Biotechnology compounds appear to be governed by their own authority. This "past" takes place in what science fiction critics would call our immediate future. The depiction of the future presented in this speculative novel can be used as a plausible projection of ethical issues biotechnology students may be confronted with in their future careers and thus raises highly relevant questions regarding the ethical side to their future work.

One such passage that lends itself particularly well to analysis with biotechnology students is the visit to the scientific university, Watson-Crick (see Appendix for extract), in which everything is artificial, from the fake rocks (named "Rockulators") which act as "natural lawn regulators" to the butterflies. There is a lexical insistence on the artificiality of all things with a predominant lexical field of created artifice: the verbs "create", "developing" (both repeated twice) and the adjective "fake" (repeated six times within twenty lines), as well as the term "splices", which refers here to the combining of two species (the institute's mascot is itself a "spoat/gider", a combination of a goat and a spider).

There are also several references to the fact that these scientists are "playing God". Things that are "real" (i.e. that "occur in nature") are opposed to things that are "fake" and "created by the hand of man". According to Crake, the bioengineer, what we are seeing is but different degrees of artificiality, which he compares to such more or less 
common practices as dyeing your hair, getting your "teeth done" or cosmetic surgery. The creations fictionalised are just artificiality pushed a little further.

Another important element in this passage is the economic aspect underlined by the author. The rich scientific university, Watson-Crick, is opposed to Martha Graham, the "poor" Humanities university that the main character attends. At Watson-Crick, there is a "bronzed statue in the entrance", "beautifully laid out extensive grounds", "security walls" and "electric golf carts to move from one place to another". The students' inventions lead to financial gain, thus providing students with an opportunity to explore the lexical field related to economics with terms such as "money-spinner" (cf. "to spin a web"), "slogan", "royalties", "market", "franchise", "investors", "price”, etc.

Most interesting perhaps, is the possibility to focus on the question of ethics as vectored by the main character's change of heart, from awe to horror, as he learns more and more about the scientific activities taking place within the walls of this institution. Although Jimmy seems impressed and intrigued in the beginning, asking questions about "how do these things work?", his feelings change completely when he is shown an "objectified" chicken (designed to become a commercial product called "ChickieNobs") that the scientists are "growing" in their laboratories. Terms such as "object" and "thing" (repeated three times) are used to refer to the chicken which is described as "a large bulblike object" and which appears to be headless. ${ }^{23}$ As Crake explains, there are "no eyes or beak or anything, they don't need those". Faced with Jimmy's horror, the scientists with him express their cold scientific point of view and even laugh at him for feeling horrified, "The woman gave her jocular woodpecker yodel, and explained that they'd removed all the brain functions that had nothing to do with digestion, assimilation, and growth. [...] 'And the animal-welfare freaks won't be able to say a word, because this thing feels no pain"', she adds.

This entire passage exposes the problems that arise when there are no more ethical boundaries and bioengineering students are given a freeway to create whatever they want under the pretext that it brings money to the university. It illustrates some of the major debates in today's society, as, for example, the use of ersatz and/or synthetic products as opposed to "natural" ones, or the economic and political implications of allowing "scientists" to have access to such "god-like" power and the possible dangers it can lead to, such as the horrifying "ChickieNobs"-which may not be that far-fetched when one takes a closer look at the food industry nowadays. Students could be asked to pinpoint what exactly provokes Jimmy's change of heart when faced with the "ChickieNobs": what is it about them that inspires horror whereas the other creations (splices, rocks, butterflies) were regarded as interesting? An additional creative and fun activity could be to get the students to invent their own splices, to provide names and scientific descriptions for these entities, such as, for example, a cross between a duck and a frog (a fruck), a duck with (edible) legs which could hop out of the water and be able to reproduce in greater numbers using frogspawn, thus doing away with the comparatively slow and laborious process of laying eggs.

Other extracts from the novel pose more existential questions, such as, for example, the visit around Crake's work facilities, during which he introduces his "life work", i.e. the "Crakers", to Jimmy. The fact that they are placed, naked, in a Garden of Eden-like dome in a sector of the laboratory called "Paradise" and are called Crakers-i.e. after their Creator who, like God, has created them in his own image-are clear references to the way in which the bioengineer sees himself as a real-life God. Mistaking them at first for 
robots, Jimmy asks what they are and is told that they are "floor models", like in "furniture stores". The Crakers' humanity is thus called into question from the start since they are perceived as artificial objects rather than living beings, even though they originate from human embryos which undergo scientifically-induced alteration. Most human "destructive features" have been eliminated from them: notions of racism, hierarchy, territoriality... They are herbivores who come into heat at regular intervals and require no houses, clothes or other material possessions, meaning that "they would have no need to invent any harmful symbolisms, such as kingdoms, icons, gods, or money" (Atwood, 2003: 359). These "models" are created for a specific market, that of parents wishing to "choose" their baby's features, whether physical, mental or spiritual. They represent the "art of the possible". This fictional depiction of eugenics naturally invites comparison with other science fiction novels, films or video games which also fictionalise different aspects of eugenics, such as Aldous Huxley's Brave New World (1931), Andrew Niccol's film Gattaca (1997) or the videogame BioShock (2007) developed by $2 \mathrm{~K}$ Boston. An obvious classroom activity in this context would be an in-class debate on genetic engineering and embryo preselection, and the possible consequences for society, a subject that directly concerns future bioengineers.

As seen, in addition to the science it contains, Oryx and Crake also offers rich material for discussion within an ESP programme for biotechnology students concerning the ethical side of their future work and the potentially dystopian consequences of human hubris arising from bioengineers being allowed to "play God".

\section{Conclusion}

As this study shows, science fiction and science are closely intertwined, at least in the fiction which strives, as far as possible, to "get the science right". Using science fiction in S\&T classes allows for the study of the science present in the narrative and the relevant terminology related to the students' domain of speciality, as well as an idea of the potential societal consequences of such research in the real world. In the context of this study, we have focused on two science-related areas: firstly, the importance of science popularisation and need to be able to explain the science behind the fiction to nonspecialists, nowadays considered an integral part of the scientist's job; and, secondly, the ethical questions in which science is grounded, notably with regard to the potential dystopian consequences of placing science beyond human considerations.

\section{BIBLIOGRAPHY}

ALDISS Brian W. \& WINGRovE David (1988), Trillion Year Spree. The History of Science fiction [1973, 1986], New York: Avon Books. 
ANDRÉOLLE, Donna (2004), "How scientific is science fiction? From Scientifiction to cyberpunk", M. PETIT \& S. ISANI (eds.) (2004), Aspects de la fiction à substrat professionnel, Bordeaux: Université Bordeaux 2, 153-164.

ASHLEY Mike (2000), The Time Machines, Liverpool: Liverpool University Press.

BAUDIN Henri (1971), La science-fiction, Paris: BORDAS Connaissance.

DEGRASSE TYSON Neil (2007), Death By Black Hole and Other Cosmic Quanderies, New York: W.

W. Norton \& Company.

DEGRASSE TYSON Neil (2014), Space Chronicles: Facing the Ultimate Frontier, New York: W. W. Norton, Incorporated.

FRIES Marie-Hélène (2016), Nanomonde et nouveau monde. Quelques métaphores clés sur les nanotechnologies aux États-Unis, Grenoble: ELLUG.

GERNSBACK Hugo (1921), "Fifty Years Hence”, Practical Electrics, 1/1.

GERNSBACK Hugo (1926), “A New Sort of Magazine”, Amazing Stories, 1(1).

GUNN James (n. d.), “Teaching science fiction”, on line: <http://www.sfcenter.ku.edu/

teaching.htm>.

HAWKING Stephen (1988), A Brief History of Time: From the Big Bang to Black Holes, London: Space Time Publications.

ISANI Shaeda (2009), "Specialised fictional narrative and lay readership: bridging the accessibility gap”, ASp, revue du GERAS, 56(2): 45-65

LANGLET Irène (2006), La science-fiction, Lecture et poétique d'un genre littéraire, Paris: Armand Colin. PARSONS Paul (2006), The Science of Doctor Who, London: Icon Books.

ROSEN Rebecca J. (2013), “Why Today's Inventors Need to Read More Science-fiction”, The Atlantic, <http://www.theatlantic.com/technology/archive/2013/09/why-todays-inventors-need-to-readmore-science-fiction/279793/>.

RUAUD André-François \& CoLSON Raphaël (2014), Science-fiction, Les frontières de la modernité, SaintLaurent-d'Oingt: Les Editions Mnémos.

SADOUL Jacques (1973), Histoire de la science-fiction moderne, Paris: Editions J'ai Lu, Albin Michel.

SCHARF Caleb (2012), Gravity's Engines: The Other Side of Black Holes, London: Allen Lane.

SCHARF Caleb (2013), "In Defense of Metaphors in Science Writing”, Scientific American, <https:// blogs.scientificamerican.com/life-unbounded/in-defense-of-metaphors-in-science-writing/>. THORNE Kip (2014), The Science of Interstellar, New York: W. W. Norton \& Company.

PRIMARY SOURCES

Novels

ATWOoD Margaret (1996), The Handmaid's Tale [1985], London: Vintage Books.

ATwOoD Margaret (2003), Oryx and Crake, London: Virago Press.

GERNSBACK Hugo (1925), Ralph 124C 41+, Nebraska: University of Nebraska Press.

HUXLEY Aldous (1932), Brave New World, London: Chatto and Windus. 
MORE Thomas (1992), Utopia [1516], New York: A Norton Critical Edition (Translated and edited by Robert M. Adams), New York: W.W. Norton \& Company.

ORWELL George (1949), Nineteen Eighty-Four, London: Secker and Walburg.

SAGAN Carl (1985), Contact, New York: Simon and Schuster.

SHELLEY Mary (1992), Frankenstein [1818], London: Penguin Classics.

Films

ANDERSON Paul (1997), Event Horizon, Paramount Pictures.

LEVINSON Mark (2013), Particle Fever, Abramorama, BOND360.

NIccol Andrew (1997), Gattaca, Columbia Pictures.

NOLAN Christopher (2014), Interstellar, Paramount Pictures, Warner Bros Pictures.

WILLUMSEN Gail (2015), The Science of Interstellar [documentary].

ZEMECKIS Robert (1997), Contact, Warner Bros.

Video games

BioShock (2007), 2K Games.

Half-Life (1998), Valve.

Space Engineers (2013), Keen Software House.

Space Invaders (1978), Taito.

\section{APPENDIXES}

\section{Extract from Oryx and Crake by Margaret Atwood (pages 234-239) ${ }^{1}$}

Compared with Martha Graham [Snowman/Jimmy's university which specialises in Humanities], Watson-Crick [Crake's university, which specialises in science] was a palace. At the entranceway was a bronzed statue of the Institute's mascot, the spoat/gider-one of the first successful splices, done in Montreal at the turn of the century, goat crossed with spider to produce high-tensile spider silk filaments in the milk. The main application nowadays was bulletproof vests. The CorpSeCorps ${ }^{2}$ swore by the stuff.

The extensive grounds inside the security walls were beautifully laid out: the work, said Crake, of the JigScape Faculty. The students in Botanical Transgenics (Ornamental Division) had created a whole array of drought-and-flood-resistant tropical blends, with flowers or leaves in lurid shades of chrome yellow and brilliant flame red and phosphorescent blue and neon purple. The pathways, unlike the crumbling cement walks at Martha Graham, were smooth and wide. Students and faculty were beetling along them in their electric golf carts.

Huge fake rocks, made from a combo-matrix of recycled plastic bottles and plant material from giant tree cacti and various lithops-the living-stone members of the Mesembryanthemaceae-were dotted here and there. It was a patented process, said Crake, originally developed at Watson-Crick and now a nice little money-spinner. The fake rocks looked like real rocks but weighed less; not only that, they absorbed water during periods 
of humidity and released it in times of drought, so they acted like natural lawn regulators. Rockulators, was the brand name. You had to avoid them during heavy rainfalls, though, as they'd been known to explode.

But most of the bugs had been ironed out, said Crake, and new varieties were appearing every month. The student team was thinking of developing something called the Moses Model, for dependable supplies of fresh drinking water in times of crisis. Just Hit It With a Rod, was the proposed slogan.

"How do these things work?" asked Jimmy, trying not to sound impressed.

"Search me," said Crake. "I'm not in NeoGeologicals."

"So, are the butterflies - are they recent?" Jimmy asked after a while. The ones he was looking at had wings the size of pancakes and were shocking pink, and were clustering all over one of the purple shrubs.

"You mean, did they occur in nature or were they created by the hand of man? In other words, are they real or fake?"

"Mm," said Jimmy. He didn't want to get into the what is real thing with Crake.

"You know when people get their hair dyed or their teeth done? Or women get their tits enlarged?"

"Yeah?"

"After it happens, that's what they look like in real time. The process is no longer important."

"No way fake tits feel like real tits," said Jimmy, who thought he knew a thing or two about that.

"If you could tell they were fake," said Crake, "it was a bad job. These butterflies fly, they mate, they lay eggs, caterpillars come out."

"Mm," said Jimmy again.

$[\ldots]$

On day one they toured some of the wonders of Watson-Crick. Crake was interested in everything - all the projects that were going on. He kept saying "Wave of the future," which got irritating after the third time.

First they went to Décor Botanicals, where a team of five seniors was developing Smart Wallpaper that would change colour on the walls of your room to complement your mood. [...]

Next they went to NeoAgriculturals. AgriCouture was its nickname among the students. They had to put on biosuits before they entered the facility, and scrub their hands and wear nose-cone filters, because what they were about to see hadn't been bioformproofed, or not completely. A woman with a laugh like Woody Woodpecker led them through the corridors.

"This is the latest," said Crake.

What they were looking at was a large bulblike object that seemed to be covered with stippled whitish-yellow skin. Out of it came twenty thick fleshy tubes, and at the end of each tube another bulb was growing. 
"What the hell is it?" said Jimmy.

"Those are chickens," said Crake. "Chicken parts. Just the breasts, on this one. They've got ones that specialize in drumsticks too, twelve to a growth unit."

"But there aren't any heads," said Jimmy. He grasped the concept - he'd grown up with sus multiorganifer ${ }^{3}$, after all - but this thing was going too far. At least the pigoons of his childhood hadn't lacked heads.

"That's the head in the middle," said the woman. "There's a mouth opening at the top, they dump the nutrients in there. No eyes or beak or anything, they don't need those."

"This is horrible," said Jimmy. The thing was a nightmare. It was like an animal-protein tuber.

"Picture the sea-anemone body plan," said Crake. "That helps."

"But what's it thinking?" said Jimmy.

The woman gave her jocular woodpecker yodel, and explained that they'd removed all brain functions that had nothing to do with digestion, assimilation, and growth.

"It's sort of like a chicken hookworm," said Crake.

"No need for added growth hormones," said the woman, "the high growth rate's built in. You get chicken breasts in two weeks - that's a three-week improvement on the mostefficient low-light, high-density chicken farming operation so far devised. And the animal-welfare freaks won't be able to say a word, because this thing feels no pain."

"Those kids are going to clean up," said Crake after they'd left. The students at WatsonCrick got half the royalties from anything they invented there. Crake said it was a fierce incentive. "ChickieNobs, they're thinking of calling the stuff."

"Are they on the market yet?" asked Jimmy weakly. He couldn't see himself eating a ChickieNob. It would be like eating a large wart. But as with tit implants- the good onesmaybe he wouldn't be able to tell the difference.

"They've already got the takeout franchise operation in place," said Crake. "Investors are lining up around the block. They can undercut the price of everyone else."

\section{NOTES}

1. In spite of this, we note that periodicals specialising in science fiction have attracted academic work for a long time, such as, for example, Foundation, the Review of Science Fiction, founded in 1972 in the UK, Science Fiction Studies, founded in 1973 and Extrapolation, founded in 1959, both in the USA.

2. FASP, or fiction à substrat professionnel is a genre identified by Petit in 1999 characterised by the fact that characters and plot are immersed in a professional or specialised environment which also feeds the denouement. See Editor's Preface.

3. The British writer Brian Aldiss also supports this opinion in the first chapter of his essay Trillion Year Spree: The History of Science Fiction (1973), entitled "The Origins of the Species: Mary Shelley". This work has often been reedited and was updated in 1986 in collaboration with David Wingrove. 
4. Jacques Sadoul, who wrote his Histoire de la science-fiction moderne in 1973, divides his chronology of science fiction into 7 periods. He quotes Jules Verne and H.G. Wells as definite models for the writers of what he calls the first period, the "foundation" period, of science fiction, which goes from 1911 to 1925.

5. Term used in his first magazines Modern Electrics (1908) and Amazing Stories (1926).

6. A film was made about CERN and the discovery of the Higgs Boson particle and gravitational waves: Particle Fever (2013).

7. Created in 2009, 60 symbols describes itself as "cool videos about physics and astronomy" on YouTube. The series became so popular that it was extended and went from the original sixty episodes to hundreds more which continue to be uploaded to the video-sharing platform today, with nearly 600,000 subscribers and an average of around 100,000 views per video. Some videos, such as the "Relativity Paradox", have been viewed by 664,000 people.

8. PBS Space Time is hosted by Matt O'Dowd who completed his Ph.D. at NASA's Space Telescope Science Institute and is now a professor at the City University of New York's Lehman College and an Associate at the American Museum of Natural History's Hayden Planetarium. This YouTube channel has over 730,000 subscribers and nearly 45 million views overall.

9. The Science of Dr Who is also a televised lecture by physicist Brian Cox.

10. Paul Parsons, who holds a DPhil in cosmology, explains for example how, in the popular British TV series Doctor Who, it is in fact possible for the Doctor's TARDIS (acronym for "Time and Relative Dimension in Space", a spaceship/time machine) to be bigger on the inside than on the outside thanks to exotic matter and its negative mass.

11. Neil DeGrasse Tyson presides talks such as the Isaac Asimov debate, a panel series which takes place every year, bringing together leading scientists who debate "pressing questions on the frontier of scientific discovery" (description on the official website of the event: http:// www.amnh.org/our-research/hayden-planetarium/asimov-debate/). These talks gather a wide audience both physically and virtually thanks to the live streaming of the event on the internet. Last year's topic (2016) was "Is the Universe a Simulation?". Guest speakers are generally theoretical physicists, physicists and astrophysicists, specialised journalists as well as philosophers, and all are reunited under the science fiction writer Asimov's heritage.

12. Gernsback's strict requirement regarding scientific accuracy in his magazine resulted however in fiction that stimulated invention but did not really have much entertainment value. This became a dilemma for Gernsback when faced with his rivals, pulp magazines, which were bright and bold and held little regard for scientific accuracy.

13. Even though the literary style of his story may be faulted, according to Sadoul, it is interesting in that it projects itself into the future and predicts what life will be like with future technological innovation, which is what many sci-fi stories will focus on.

14. During a conference in Copenhagen on $24^{\text {th }}$ November 2014 called "Science and Cocktails", "an initiative that brings science and entertainment closer together" (as explained on their official website), Kip Thorne explains how he made Nolan read about 30 "science books" before brainstorming with him about the film, and issued guidelines insisting that, "Nothing in the film will violate firmly established laws of physics, or our firmly established knowledge of the universe" and "Speculations about poorly understood physical laws and the universe will arise from real science." Nolan agreed to all this "as long as it didn't get in the way of making a great movie".

15. Interstellar is of course not the first film to use the wormhole to suit its narrative and the very same Kip Thorne had already advised Karl Sagan on wormholes when he wrote his novel (which was later made into a film) Contact (1985).

16. The extract can be seen on: <https://www.youtube.com/watch?v=MywwqjqKF6Y>

17. The extract can be seen on: <https://www.youtube.com/watch?v=PtyyslBW6kk> 
18. Originally referred to as "Einstein-Rosen bridges", they became "wormholes" in the 1950s as the term was coined by the Princeton physicist John Wheeler "who likened Einstein-Rosen bridges to the tunnels made by a worm burrowing into an apple-the straight-line distance through a tunnel from one side of the apple to the other being shorter than the distance around the apple's surface" (Parsons, 2006: 35-37).

19. In the $6^{\text {th }}$ chapter of A Brief History of Time (1988), Stephen Hawking describes the effect of the black hole on an astronaut as he enters the event horizon as "Th[e] difference in the forces would stretch our astronaut out like spaghetti or tear him apart" (97).

20. Abbreviated to $t 1 / 2$, it refers to the time required for a quantity to reduce to half its initial value and is particularly used to study the reaction of unstable or stable atoms faced with radioactive decay. The term "half-life" is more generally used to characterize different forms of decay. Coined by Ernest Rutherford in 1907, the original term was "half-life period", subsequently reduced to "half-life" in the 1950s.

21. The extract can be seen on: <https://www.youtube.com/watch?v=oEg016JaW4Y>.

22. The extract can be seen on: <https://www.youtube.com/watch?v=0uuMramPpj4>.

23. This inevitably brings to mind the expression "running around like a headless chicken", thus inviting metaphoric analogy with the idea of science running doing a lot of things but not very effectively or even totally out of control.

\section{Notes de l'annexe}

1. The passage corresponds to one of Snowman's many flashbacks to his and his friend Crake's university life.

2. Corporation Security Corps, a private security firm.

3. The official name of 'pigoons', a combination of a pig and a raccoon.

\section{ABSTRACTS}

The aim of this paper is to see how science fiction can be used in the ESP classroom with Science and Technology students. Following on from previous work in this field, this paper explores how we can make space for science fiction in ESP teaching, and on what grounds. We first show how passages from science fiction novels such as Margaret Atwood's Oryx and Crake, films like Interstellar and video games like Half-Life can be used effectively with students specialising in biotechnology or astrophysics. Our aim is to both analyse the scientific content of these works of fiction and appreciate the educational dimension of the genre and what it can bring to S\&T students, in terms of both science and ethical questioning. We start with a brief historical overview of science fiction as a popular genre, its beginnings, and its role with regard to science popularisation. We then proceed to analyse its pedagogical potential and present specific examples of the possibilities these works offer in the context of ESP classes for science and technology students.

L'objectif de cet article est de voir de quelle façon la science-fiction peut être utilisée dans les cours d'anglais de spécialité avec des étudiants en Sciences et Technologies. En poursuivant des travaux précédents dans ce domaine, nous examinerons les différentes façons d'exploiter la science-fiction dans l'enseignement en anglais de spécialité scientifique. Nous montrerons en quoi certains passages extraits de romans de science-fiction, tels que Oryx and Crake de Margaret 
Atwood, mais également des films comme Interstellar et des jeux vidéos comme Half-Life, peuvent être utilisés de manière efficace avec des étudiants se spécialisant en biotechnologie ou en astrophysique, à la fois en termes de science et de questionnement éthique. Dans une première partie, nous commençons avec un bref aperçu historique de la science-fiction en tant que genre, ses débuts et son rôle dans la vulgarisation du discours scientifique. Dans une deuxième partie, nous évoquons son potentiel pédagogique pour ensuite présenter quelques exemples spécifiques de la façon dont ces œuvres peuvent être exploitées dans les cours d'anglais de spécialité scientifique.

INDEX

Keywords: Science fiction, English for Specific Purposes, popular science, astrophysics, biotechnology

Mots-clés: Science-fiction, anglais de spécialité, didactique, vulgarisation scientifique, astrophysique, biotechnologie

\section{AUTHOR}

\section{MARIE THÉVENON}

Université Grenoble-Alpes (France) 